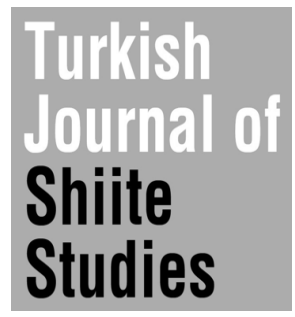

ISSN: 2687-1882

Cilt | Volume: 3

Say1 | Issue: 1

Haziran | June 2021

\title{
The Bektashi Order, Sufism, and Shi' 'ism in the Work of Baba Rexheb, a Bektashi Sufi of 20th Century
}

20. Asrın Bektaşi Sûfîsi Baba Receb'in Çalışmalarında Sûfîlik, Şiîlik ve Bektaşi Tarikatı

\author{
SeyedAmirHossein Asghari \\ Dr., Indiana University, Department of Middle Eastern Languages and Cultures \\ İndiana Üniversitesi, Ortadoğu Dilleri ve Kültürleri Bölümü \\ Bloomington, IN./USA \\ sasghari@iu.edu https://orcid.org/0000-0001-8850-7591
}

\author{
Makale Bilgisi | Article Information \\ Makale Türü | Article Type: Araştırma Makalesi | Research Article \\ Geliş Tarihi | Date Received: 24.09.2020 \\ Kabul Tarihi | Date Accepted: 27.04.2021 \\ Yayın Tarihi | Date Published: 30.06.2021 \\ DOI: https://doi.org/10.48203/siader.799560
}

Atıf | Citetion: Asghari, Seyed Amir Hossein. "The Bektashi Order, Sufism, and Shì'sm in the Work of Baba Rexheb, a Bektashi Sufi of 20th Century". Turkish Journal of Shiite Studies 3/1 (June 2021): 51-74. doi: $\underline{10.48203 / \text { siader.799560 }}$

İntihal: Bu makale, ithenticate yazılımınca taranmıştır. İntihal tespit edilmemiştir. Plagiarism: This article has been scanned by ithenticate. No plagiarism detected. 


\begin{abstract}
The Bektashi order is known for its Shìi roots. However, there are contradictory interpretations in determining the origins or teachings of the Bektashi order. This paper studies the Bektashi order focusing on Mysticizma Islame dhe Bektashizma by Baba Rexheb (1901-1995). I argue that his work plays a vital role in explaining traditional Bektashi thought and its transition to the modern era. This paper attempts to illustrate the Bektashi order's pertinence to Sufism and Shì'i Islam through his work. Albert Doja (2006) and Yuri Stoyanov (2012) have criticized Mysticizma Islame dhe Bektashizma for attempting to "drastically change the Bektashi Order" or "what they can manage to do with their ideological schemes when their prestige is at stake". This paper will access those claims by considering Baba Rexheb's works, and the account of his life portrayed in The Sufi Journey of Baba Rexheb (2009) and other resources. In what continues, it tries to explain that those modern claims in discrediting Baba Rexheb's work are historically unlikely.
\end{abstract}

Keywords: The Bektashi Order, Bektashi Creeds, Shī’šsm, Baba Rexheb, Sufism

\title{
Öz
}

Bektaşi tarikatı Şiî kökleriyle tanınır. Ancak Bektaşi tarikatının kökenleri veya öğretilerini tespit etme noktasında çelişkili iddialar söz konusudur. Bu makale Bektaşi tarikatını, Baba Receb'in (1901-1995) Mysticizma Islame dhe Bektashizma isimli eserini merkeze alarak incelemektedir. Bana göre onun bu çalışması geleneksel Bektaşi anlayışını açıklamada ve bu anlayışın modern döneme uyumlu hale getirilmesinde hayati role sahiptir. Bu makâlede, onun bu eseri üzerinden Şiîlikle tasavvufun uyumu noktasında Bektaşi tarikatının örnekliği üzerinde durulmaktadır. Albert Doja (2006) ve Yuri Stoyanov (2012) Mysticizma Islame dhe Bektashizma'yı "Bektaşi tarikatında köklü değişim" veya "prestijleri tehlike altında olduğunda insanların fikri duruşlarında ne tür dönüşümlere başvuracakları" noktasında ele almışlardır. Bu makalede, Baba Receb'in kendi eserleri, The Sufi Journey of Baba Rexheb (2009) ve diğer kaynaklardaki hayatıyla ilgili bilgileri temel alınarak söz konusu iddialar incelenecektir. Devamında Baba Receb'in çalışmasının itibarını sarsan bu modern iddiaların tarihsel olarak temelsiz olduğu kanıtlanmaya çalışılacaktır.

Anahtar Kelimeler: Bektaşi Tarikatı, Bektaşiliğin Kökenleri, Şî̂lik, Baba Receb, Sûfîlik 


\section{Introduction}

The distress placed by Communist policymakers of Albania (1944-1991) on religious communities in general and the Bektashi Order, in particular, is uncountable. ${ }^{1}$ The result of their policies was a ban on any kind of teaching and practice of religion on the one hand, and destroying or changing the function of religious centres into state-owned public entities, or elimination of their literature and clerics on the other. Where all other religious communities of Albania ${ }^{2}$ were related or at least connected themselves to a supporting centre outside of the boundaries of the country, Bektashism had no other outside centre: Albania was home to Kryegjyshata Botërore Bektashiane (the World Headquarters of the Bektashi Order), after Ataturk's ban on all Sufi practices in 1925 in Turkey. Therefore, Baba Rexheb (1901-1995), in the introduction to his work, alludes to the insufficiency of Bektashi literature in the Albanian language. ${ }^{3}$

Historians date Bektashism back to the appearance of Ḥājī Baktāš Walī (d. ca.1271) in the thirteenth century in Anatolia. Bektashism as an organized Sufi Order, ${ }^{4}$ however, begins with the emergence of Pīri Thānī known as Bālīm Sūltān (1457-1517) in the fifteenth century. Throughout its history, the Bektashi Order produced its own Sufi literature, poetry (Turkish: nefes) and practical Sufi rituals. The number of such works is beyond counting, but they include outstanding literature that emphasizes Bektashi doctrines and esoteric interpretation of Scripture, the nature of God, humans and the

It was not only Albania that was affected. The Bulgarian historian and anthropologist Nevena Gramatikova, in her "Changing Fates and the Issue of Alevi Identity in Bulgaria" narrates how the post-communist Alevi generation lost their identity and how she managed to learn about her religious identity. see: Nevena Gramatikova and International Centre for Minority Studies and Intercultural Relations., NeortodoksalniiāT IsliàM V BŭLgarskite Zemi : Minalo I SŭVremennost, 1. izd. ed. (Sofiīa: IK "Gutenberg", 2011). Nevena Gramatikova, "Ethnology of Sufi Orders: Theory and Practice. Proceedings of the British-Bulgarian Workshop on Sufi Orders" (paper presented at the the British-Bulgarian Workshop on Sufi Orders, 2000). For more on the notion and definition of Alevi and Bektashi see Cenksu Üçer, Tokat Yöresinde Geleneksel Alevîlik (Ankara: Ankara Okulu Yayınları, 2015). Harun Yıldız, Anadolu Aleviliği : Amasya Yöresi Bağlamında Bir İnceleme (Ankara: Ankara Okulu Yayınları, 2014). Fevzi Rençber, Hakk Muhammed Ali Aşkı : "Adıyaman Alevileri" (2014). For more on retuals see Baharlu, ilgar. "Safevîler Döneminde Sema (Semah) (Kronikler, Seyahatnâmeler ve Minyatürlerde)". Türk Kültürü ve Hacı Bektaş Velî Araştırma Dergisi /97 (2021): 11-28. İlgar Baharlu, "Pre-Safavid Sema (Semah) Accompanied with Sufi Classics," Journal of Alevism-Bektashism Studies 22 (2020).

Including Sunni, Bektashi and Alevi communities, the Catholic and Orthodox Churches.

Rexhebi, Misticizma Islame Dhe Bektashizma (New York: Printed by Waldon Press, 1970).

The hierarchy of the Bektashi Order is usually depicted as aspirants (Ashiks, Dashamirës in Albanian), initiated disciples (myhibs, lit. lovers) and clerics of different ranks: dervishes, Babas (or prindës), gjyshs/ jūsh (or Dedes), and finally the kryegjysh (DedeBaba) at the top. For more, see Nathalie Clayer, "The Bektashi Institutions in Southeastern Europe: Alternative Muslim Official Structures and Their Limits," Die Welt des Islams 52, no. 2 (2012): 183-203. There are, however, Albanian equivalents of the Turkish terms such as Baba and Dede. However, in the Albanian Bektashi Order, the Turkish ranks are still used to refer to Baba and Dede or Dedebābā. Algar; puts the hierarchy as follows: "āăeq, mohebb, darvišs, Baba, kalifa, and-standing somewhat outside the series-mojarrad." See Hamid Algar, "Bektāšīya," in Iranica (1989). 
world. In general, it shares the Islamic Sufi idea in which Divine love and human perfection through faith and practice is a core theme. As such, Turkish mystic literature owes to Bektashi Sufis their way of understanding the Divine love and its relation to man. ${ }^{5}$

\subsection{Post-Ottoman and Modern Scholarship and Bektashism}

Post-Ottoman and modern scholars tend to define the Bektashi Order in very diverse and sometimes contradictory terms. Some have stressed the non-Islamic origins of the Bektashi beliefs. It is important to note, that a considerable amount of ethnographic studies in the Balkans during the last century have been made to serve nationalistic and ideologized policies. While some of those scholars call the Bektashi Order pagan or heterodox, others try to depict it as Sunni, Shi'a, or a mixture of paganism, Christianity and Islam. Intriguingly, in some of these studies, the Bektashi order was ascribed to be affiliated to French Masonic Lodges, and in another case to the Dönmeh Jews and Sabbatai Zevi's (1626-1676) movement. ${ }^{6}$ Stoyanov describes Ottoman Balkans historiography, especially after World War II, as tending to disregard the Islamic fundamental of their beliefs and rituals. ${ }^{7} \mathrm{He}$, moreover, stresses the fact that populist historiographers of the post-communist Balkan were inspired by the thesis of pre-Ottoman Christians that identify the Balkan's Kızllbaş (Qizilbāsh) and Bektashi community with pre-Ottoman Christians. This populist historiography "retained its appeal and potential to be politically instrumentalized." ${ }^{8}$ Clayer, on the other hand, expresses the confusion in the depiction of Bektashism and adds that there are divergences with the image of Bektashism as it is generally constructed by intellectuals as a non-Islamic Bektashism. On the other hand, there are also certainly divergences within Bektashism mainly organized locally around holy men with

\footnotetext{
Annemarie Schimmel, Mystical Dimensions of Islam (Chapel Hill,: University of North Carolina Press, 1975), 337.

$6 \quad$ Richard Davey, The Sultan and His Subjects, A new ed. (London: Chatto \& Windus, 1907), 97. It is also important to point to a reverse theory i.e. the impact of the Bektashi Order on Sabbatians. For more on this see Ada Rapoport-Albert and Deborah Greniman, Women and the Messianic Heresy of Sabbatai Zevi : 1666--1816, Littman Library of Jewish Civilization (Oxford ; Portland, Or.: Littman Library of Jewish Civilization, 2011). Also for more in Turkish resources on Zevi see Cengiz Şişman, "Sabatay Sevi," in TDV İslâm Ansiklopedisi (TDV İslâm Araştırmaları Merkezi, 2008). Antoine Galland et al., İstanbul'a Ait Günlük Hatıralar (1672-1673) (Ankara: Türk Tarih Kurumu Basımevi, 1998).

7 Yuri Stoyanov, "Contested Post-Ottoman Alevi and Bektashi Identities in the Balkans and Their Shi' ite Component," in Shi'i Islam and Identity: Religion, Politics and Change in the Global Muslim Community, ed. Lloyd V. J. Ridgeon (London; New York: I.B. Tauris : Distributed in the United States and Canada exclusively by Palgrave Macmillan, 2012), 183.
}

$8 \quad$ Ibid., 184

Turkish Journal of Shiite Studies 3/1 (Haziran 2021) 
metaphysical power. ${ }^{9}$ It is beyond the limits of this paper to Investigate all these controversial theories. We do, however, briefly consider some of them as instances of the post-Ottoman and modern scholarship on Bektashism.

In 1942, Ernest Amsaur in his "The Bektashi Dervishes and the Young Turks" emphasizes the Bektashi Order's liberal doctrines. He points out that "In its doctrines and beliefs the Bektashi Order is liberal. It is certainly not orthodox Sunnite, nor, for that matter, is it orthodox Sh'i' i te." ${ }^{10}$ On the other hand, others refer to the grouping of Allah, Muhammad and Ali in the Bektashi Order, linking it to the Christian Trinity. Robert Elsie, by keeping in mind the Shì' trend of Bektashi order, alludes to a form of a trinity: "The figures of Allah, Muhammed and Ali have thus come to constitute a sort of Bektashi trinity." ${ }^{11}$ Later, however, he emphasizes that "The Bektashi, like other Shi'ites, revere the twelve imams, particularly Ali of course, and consider themselves descendants of the sixth imam, Jafer Sadik [Arabic: Jacfar Al- Șādiq]."12 Karin Vorhoff indicates that the nature of Bektashi doctrine is different from Shi' ism: Haci Bektas Veli serves to distinguish Anatolian Alevism unequivocally from Shī'i sm as it is represented by the Islamic Republic of Iran. ${ }^{13}$ Vorhoff's paper ignores historical sequences and confuses socio-political events, movements, and interpretations with the core creeds or beliefs. Historical Shī'i sm has as a core belief the succession of Ali after the death of Muhammad. Different Shi'ite communities may follow different juristic schools but that still does not make them non-Shi'a. On the other hand, the Iranian Islamic Republic is a modern phenomenon and it is well-known that the developments of Bektashism go back to the fourteenth century AD. Vorhoff may want to express the idea that the contemporary Bektashi community of Turkey is not adhering to contemporary political Shi'ism which was developed and promoted after the Iranian Islamic Revolution in 1979. These are, however, two different fields and categorizing them together causes misunderstandings of the common core creeds of Shī'ite and Alevi groups throughout history.

The same problem appears in Stoyanov's article entitled "Contested PostOttoman Alevi and Bektashi Identities in the Balkans and their Shi ite Component" where he repeats Vorhoff's statement that anthropologists have encountered the Bektashi community's "unwillingness to associate with the modern Twelver Shī ìsm

\footnotetext{
9 Clayer, "The Bektashi Institutions in Southeastern Europe: Alternative Muslim Official Structures and Their Limits," 202.

10 Ernest Edmondson Ramsaur, The Young Turks; Prelude to the Revolution of 1908, Princeton Oriental Studies: Social Science, (Princeton, N.J.: Princeton University Press, 1957).

11 Robert Elsie, The Albanian Bektashi: History and Culture of a Dervish Order in the Balkans (London: I.B.Tauris, 2019), 44.

Ibid.

13 Karin Vorhoff, "'Let's Reclaim Our History and Culture!": Imagining Alevi Community in Contemporary Turkey," Die Welt des Islams 38, no. 2 (1998): 273.
} 
tradition of post-1979 Iran." Yet, he admits that "their belief and their ritual system make them qualify as part of the large tradition of Shi ite Islam." ${ }^{14}$ Allegedly, the above-given ideas expose confusion between religious beliefs per se and individual or community political or social trends favouring one system or another. To figure out this problem, it is helpful to refer to Schimmel's historical studies on Islamic mysticism in which she concludes, "The Bektashis have always maintained strong relations with the Imamiya-Shia in Iran." ${ }^{15}$ What Schimmel depicts is more prominent than modern political or social movements. She narrates the interaction of very core beliefs that integrate Shī'ssm and Sufism on the one hand and the expansion of a mystical interpretation of revelation from Iran to the whole Persianate world on the other.

Another interpretation describes the Bektashi Order as Shi'a extremists. (Ghulāt Shi'a). The term Ghulāt Shi'a itself, however, is a controversial expression among scholars of the Shìa Islam. The reason lies in the ambiguity of the definition of the extremist Shi'ites and what they represent. While some categorize the attribution of cosmic and metaphysical roles to the Shïa Imams as an indicator of extremism (Ghuluww), others see it as "the old esoteric tradition,"16 or a "non-rationalist tradition"17 which not only have nothing to do with "extremism," but indeed can be taken as the original form of Shï'ism. Nevertheless, Matti Moosa, for instance, in his "Extremist Shi'ites: The Ghulat Sects" includes the Bektashi Order along with Ghizilbāsh and others among the Shī'i extremist and defines extremists as "those Shi' ites who deify Imam Ali and the rest of the Imams" ${ }^{18}$ Further, in a chapter entitled "Trinity," he presents evidence for the claim that the love for Allah, Muhammad, and Ali among the Bektashi community "is so close that it amounts to a doctrine of Trinity." ${ }^{19}$ It appears that Moosa applies a literalist interpretation of the inward (Baținī) connotations of the Bektashi or Shī'i-Sufi poetry and concepts. Moosa refers to the poetries of Sefil Abdal, Perişan Baba as evidence for his claim:

Sefil Abdal writes:

"God, Muhammad, Ali, all are one secret (Allah, Muhammet, Ali hep bir sirdır)"

and Perişan Baba says:

"The Divine Reality, Muhammad, Ali are true (Hak, Muhammet, Ali haktır)"

Pir Mehmet in a nefes expresses the same thought:

Stoyanov, "Contested Post-Ottoman Alevi and Bektashi Identities in the Balkans and Their Shi'Ite Component," 191.

15 Schimmel, Mystical Dimensions of Islam, 338.

16 Mohammad Ali Amir-Moezzi, Eric Ormsby, and Hasan Ansari, "Silent Qur'an and the Speaking Qur'an: Scriptural Sources of Islam Between History and Fervor," (2016): 105.

Ibid., 106.

18 Matti Moosa, Extremist Shiites: The Ghulat Sects, 1st ed., Contemporary Issues in the Middle East (Syracuse, N.Y.: Syracuse University Press, 1987), xxiii.

19 Ibid., 132, 35-6. 
He also says:

"There is no God but God " is love (Muhabbettir Lailaheillallah)

"Muhammad the Prophet of God " is love (Muhabbettir Muhammet Resulullah)

"Ali, Prince, Saint of God" is love (Muhabbettir Ali Şah veliyullah)

Three names, in meaning one, love. (Üç isim, manada birdir muhabbet)

Love is the light which Gabriel saw (Cibrilin gördüğü nurdur muhabbet)

In the midst of God Muhammad Ali. (Allah Muhammet Ali ortasinda)

There are considerable references in Sh'î i creeds regarding the relationship between Muhammad and Ali. Based on a Shī'i interpretation and narrations of the Imams, Ali in the Quran is described as the Soul of Muhammad in 3:61, where God talks to Muhammad as follows: "Should anyone argue with you concerning him, after the knowledge that has come to you, say, Come! Let us call our sons and your sons, our women and your women, our souls and your souls, then let us pray earnestly, and call down Allah's curse upon the liars.' (Quran, 3:61)" On many other historical occasions, Muhammad calls Ali his brother or successor (Wași). Still, in many prayers of visitations, Muhammad and all infallible Imams are called upon as "One Light." Moosa's interpretation of the popular poets seems to be done regardless of the theoretical foundations of these concepts in both Shīi $\overline{1}$ and Sufi sources. The perfect man (Insan al-Kāmil), for instance, is both manifest of the name and attributes of God and His vicegerent on earth in Islamic theoretical Sufism. On the other hand, Wilāyah is the inner side of the prophethood (Nubuwwah). It is in this sense that Muhammad and Ali represent two sides of one reality. This, however, does not mean that they are incarnated or are one person, rather their spirit is of a transcendent reality that stands beyond other realities, and their soul is annihilated in their Divine beloved. The sample poetries that Moosa uses do not represent the deification of Ali. Those are the continuation of the esoteric understanding of the role of Wali which is based on certain Hadith resources.

Moosa, on the other hand, when he translates Turkish popular poetry by Sefil Abdal as "God, Muhammad, Ali, all are one secret," takes the secrecy of the relationship between Allah, Muhammad, and Ali as a Trinity or deifying Ali. As mentioned, a literal reading of an esoteric concept causes such a result as has been the case in historical debates between Sufis and their opponents. Literalist interpretations of esoteric ideas have caused countless debates among the Sufis and their opponents. ${ }^{20}$ Next, we will briefly discuss Baba Rexheb's response to this interpretation.

\footnotetext{
$20 \quad$ For more on this, see John Kingsley Birge, The Bektashi Order of Dervishes (2015). Thierry Zarcone and Angela Hobart, Shamanism and Islam: Sufism, Healing Rituals and Spirits in the Muslim World (2017).
} 


\subsection{Baba Rexheb's Life and His Contribution to the Exploration of Bektashi Doctrines}

Baba Rexheb (Albanian: Baba Rexhepi, Baba Rexheb, Arabic Rajab, Turkish: Recep) (1901-1995), was born in Gjirokaster in southern Albania. At an early age, he received a Bektashi education from Selim Ruhī Baba (1869-1944) and was thus initiated into the Order as Muhib at the age of seventeen. This master is the one who expressed the naming of Baba Rexheb as follows: Summīya Ismuhū Bi al-Rajab al-Fard Barakahu Allāhu wa 'azzahū "He was named with the name of Rajab, the Solitary. May God bless him and exalt him. ${ }^{21}$ It is important to mention that Selim Ruhī Baba was a disciple of Ali Ḥaqi Baba (d. 1907) who was authorized as Baba in Turkey by Türabi Dede. Baba Rexheb narrates the following about Ali Haqī Baba's last day of life when he asked for a pen and a paper from his Murid i.e., Selim Ruhī, and wrote a couplet in Persian. He had mastery in Turkish and Persian poetry. His pen name was Khākī. Trix provides an English translation of that line:

No friend remains for you, Khâkî, but sighs and wails

So you must say, "praise to God" that this remains for you ${ }^{22}$

Baba Rexheb advanced to the rank of Dervish at the age of twenty-one. In the tradition of Albanian Bektashism, he remained celibate and served his master for twenty years. Meanwhile, he continued his Islamic education in Gjirokastra's Medrese (Islamic School) and received his Icāzatnāme (Diploma) in 1925, which acknowledged him as a young Islamic theologian and scholar. The traditional Bektashi and Islamic education equipped him with knowledge of Arabic, Turkish, and Persian languages and literature.

It was the emergence of WWII and the challenging situation for religious authorities under the rule of the Albanian Communist party that eventually changed the pattern of Baba Rexheb's life and made him leave his Teqe (lodge, Albanian: Teqe, Turkish: Tekke, Persian: Tekye) and country. ${ }^{23}$ He escaped to the United States of

21 See Frances Trix, The Sufi Journey of Baba Rexheb, 1st ed. (Philadelphia: University of Pennsylvania Museum of Archaeology and Anthropology, 2009), 22.

22 See ibid., 42.

23 Baba Rexheb, in his conversation with Francis Trix, explains why he had to flee from Albania:

I made propaganda against Communism. So if the Communists caught me, they would have killed me. Of course, I had to go. [Selim Ruhī] Baba knew this. I said to him: 'Now there is no other way, I must be going.' 'Very well,' he said. 'Then may it go well.' I went from there, from Gjirokastra to Shkodra. From Shkodra, then by way of the sea, I came to Italy. I lived there [for] four years, in a camp. See ibid., 23. He then went to Bektashi lodge in Egypt but was concerned for its future and decided to move from there to the United States. He explains, "I went there. I stayed four years in Egypt. Then I saw that the tekke would be destroyed there. And it was not a good place for us because the Arabs didn't like us [Albanians]. Naturally, being Sunni they did not like tekkes. And a day would come when they would destroy the tekke. As a matter of fact, that is just what happened." Ibid., 24. 
America in 1953, where he was able to establish the first Bektashi Teqe in Detroit with the help of Albanian Muslim immigrants in 1954. Baba Rexheb's attempt to establish a Teqe in the United States, whether he foresaw it or not, perhaps saved the Albanian Bektashi tradition and teachings from all of the attacks and persecution of the Communist regime. In doing so, he continued to write the Bektashi teachings even though he had limited resources with him in the United States. We divide his life into three phases:

A: Becoming a celibate member of Bektashi Teqe (Sufi lodge) of Gjirokaster in Albania at an early age and gaining Bektashi knowledge and practice under the guidance of Selim Ruhī Baba (1869-1944). Selim Ruhị was himself trained by Ali Ḥaqī Baba (d. 1907) who was a disciple of Türabi Dede (d. 1868) of Turkey. This indicates that he trained under the last generation of the influental and knowledgeable traditional Bektashi Sufis at the end of the Ottoman Empire and before the Communism era, after which gaining traditional Bektashi knowledge from a master was not easy.

B: Escaping the limitations caused by the prohibition of practicing religion in Communist Albania and moving to the United States of America, where he founded the Bektashi lodge in the Detroit suburb of Taylor with the help and collaboration of the Albanian Bektashi community in exile.

C: Composing the Misticizma Islam dhe Bektashizma and reviving other Bektashi teachings for post-communist readers in particular who had lost their connection with their tradition under the Communist regime. It is worth mentioning that traditionally, the Bektashi teaching was mostly passed orally from one generation to another. Based on Baba Rexheb's claim in his introduction to Misticizma Islame dhe Bektashizma, this is the first book of its kind written in the Albanian language. ${ }^{24}$

\subsection{Baba Rexheb, Islamic Mysticism, and the Bektashi Order}

Misticizma Islame dhe Bektashizma ${ }^{25}$ (Islamic Mysticism and Bektashism) was written in 1969 and first published in 1970 in Michigan. Later on, selections of the book were translated into English by Bardhyl Pogoni (1925-1985) and published in 1985.

24 Rexhebi, Misticizma Islame Dhe Bektashizma..

25 Misticizma Islame dhe Bektashizma is one of the most-read books by a Bektashi Sufi of the modern era. Clayer quotes Metin Izeti's remark that the most read books among the Bektashi community are as follows: Baba Rexheb's Misticizma Islame dhe Bektashizma, Na`īm Frashëri's Fletore e Bektashinjët and Qerbelaja/Karbala Mathnawi and the "Hadikatus Suada" ("Hadīqah al-Su'adā") by Muhammad b. Sulaymān Fuḍ̄lī (885 ?963/1480?-1556), (in Turkish Fuzūīi). Hadīqah is a Turkish translation drawn from the "Rawdat al-shuhadā’ of Ḥusayn Wāciz Kāshifī" read during the period of matam/matem (beginning of the month of Muharram). Clayer, "The Bektashi Institutions in Southeastern Europe: Alternative Muslim Official Structures and Their Limits," 203. 
Regarding its importance, there are several factors to be considered. One is the author himself, who, as a Bektashi Sufi, received his knowledge of Bektashism from traditional mentors in pre-communist Albania and late Ottoman Turkey. Moreover, the book includes not only Bektashi teachings, but also theoretical concepts of Islamic mysticism and hagiographies of some Sufi saints. Therefore, it covers a broader area than the Bektashi Order, putting it into a historical or phenomenological conversation with the history of the Islamic Sufi tradition. On the other hand, the Bektashi World Headquarters in Albania acknowledged this book as an essential source of the Order and its creeds. Misticizma Islame dhe Bektashizma, therefore, plays a significant role in articulating Bektashi's history and beliefs for its followers. ${ }^{26}$

Misticizma Islame dhe Bektashizma is divided into two parts, each containing several chapters. The first part includes, as mentioned briefly, the history of Sufism, its definitions and roots, Sufi terminology, and short biographies of great Sufis. Baba Rexheb uses this part to tie Bektashi's beliefs to the general history of Sufism. He begins with a definition of Islamic Sufism and Spirituality. According to him, Spirituality is the awareness that leads to human perfection; it endows individuals with virtuous conduct and frees them from worldly concerns. Only then can a person achieve the ultimate goal, which is total unification with the Beloved: God Almighty. ${ }^{27}$ This practice is then what leads man to the path of perfection, equipped with all moral principles along with His love. ${ }^{28}$ Baba Rexheb defines Sufism based on both theoretical and practical elements. As a result of wayfaring, "man will become sacred, reaches to the highest steps of morals, and discovers the hidden treasures (Kanz Makhfi) and merges and remains in the throne of God which in the Sufi terminology is called 'subsistence with God' (Baqā' Billäh)." ${ }^{29}$ He discusses the unity of God (Tawhìd) and provides an interpretation of some Quranic verses such as 21:30 and 66:8 to allude to the discussion of the Unity of Being or the Unity of Existence (wahdat al wujūd) $)^{30}$ and

\footnotetext{
Mainly in the Albanian-speaking lands such as Albania, Kosovo, and Macedonia. Rexhebi, Misticizma Islame Dhe Bektashizma, 1. Chittick argues that this is misleading, for Ibn 'Arabī never applied this expression in his works. He rather used "Real Being" and that real being is One, arguing that there is no Real Being but God and that everything other than God is unreal being. Chittick argues that this is comparable to Avicenna's position that all things are possible or contingent save the Necessary Being. Even when this expression is used by immediate followers of Ibn 'Arabī, Chittick argues that they did not give it a technical sense. See William Chittick, "Ibn "Arabî," in The Stanford Encyclopedia of Philosophy ed. Edward N. Zalta (Spring 2020 Edition).
} 
Muhammadan Reality. To some, this may suggest a turn to Akbarian mystical theology in the Bektashi Order or to that of the Qizilbāsh or Ḥurūfĩ movements. ${ }^{31}$

In the first chapter, the author explains how Sufism developed in history after the emergence of Islam. Baba Rexheb writes, "Islamic mysticism did not emerge on its own (i.e., out of nowhere), rather it appeared gradually...every Muslim at that time knew that he/she must pray to God wholeheartedly ...and it was known that extraordinary prayers (Nāfile) were a great reward from God." ${ }^{132}$ He shows that the "Sufi" practice was constituted in the daily practice and beliefs of the early Muslims. Later on, however, forgetfulness and worldly desires caused them to distance themselves from many of those practices. As a result, it was the great endeavor of Sufis to revive the spiritual tradition in later periods. He then returns to the description of Islamic Sufi terminology before recounting the emergence of Sufism in Iraq and the history of Sufism in later periods.

Baba Rexheb mentions some Sufi definitions of the term Sufi and Islamic Sufism and designates that the various meanings of Sufism are rooted in and based on the varying states of individuals who tried to define it, but in the end, they have a common ground. As he explains in his book, all definitions of Sufi allude to a single reality which is self-purifying (Albanian: pastrimin e shpirtit) and provides salvation from worldly desires while combating with ego ( $\mathrm{Nafs}$ ). He argues that the reason is that the prophetic tradition stands in contrast to all worldly passions.

One of the Baba's resources for Sufi definition is the famous book Kitāb al-Ta'arruf li Madhhab Ahl al-Tasawwuf by Abu Bakr al-Kalābādhī (d.380/990), one of the earliest extant Sufi authors. By appealing to this text, Baba Rexheb, despite some of the mentioned theories, neither depicts an isolated nor a mixed Bektashi order. As a Baba in the Bektashi Order, he follows the broad Sufi tradition in exploring its nature. $\mathrm{He}$ then presents some of those definitions:

- The Sufi is he whose heart is sincere (safā) towards God.

- The Sufi is he whose conduct towards God is sincere, and towards whom God's blessing is sincere. ${ }^{33}$

As such, he refers to Ibn 'Arabi and his school of thought and with sympathy explains concepts such as the Perfect Man, the Oneness of Being or the Unity of

31 The influence of Hurufism into the Bektashi Order is also debated and discussed among the scholars. for more, see: Edward Granville Browne, Further Notes on the Literature of the Hurufis and Their Connection with the Bektashi Order of the Dervishes ([Hertford]: [S. Austin], 1907).

32 Rexhebi, Misticizma Islame Dhe Bektashizma, 2.

33 Ibid., 29. Both definitions among the others are quoted from Kalābaādhī's Kitab al-Ta'arrufli Madhhab Ahl alTasawwuf. We also used A.j. Arberry's 1935 translation of Kalābaādhī's in this section. See Abu Bakr Muhammad Ibn Ibrahim al-Kalabadhi and A. J. Arberry, "The Doctrine of the Sufis = Kitab Al-Taarruf LiMadhhab Ahl Al-Tasawwuf," (1977). 
Existence (Wahdat al-Wujūd), Muhammadan Reality, Qutb and his role in Sufism and suchlike. He focuses on Islamic mysticism, its saints, theoretical and practical aspects, and finally, after this contextual introduction, he introduces Bektashi's beliefs and thoughts to the reader.

To speak about Sufism without any doubt, Baba Rexheb refers to the verses of Qur'ān and Prophetic traditions (hädith). He, however, expresses that Spirituality is not limited to Islam and has old roots, and makes it clear that Muslim Sufis have said that Islamic Sufism draws from Islam itself, from the holy Quran, divine sayings (Hadith Qudsi/ Alb: Hadithi Kudsi), ${ }^{34}$ from the life and practice of prophet Muhammad and his prophetic traditions (hadith). Although he indicates the ancient history of mysticism, nevertheless, he does not confirm that the Bektashi creed as a Sufi Order is a "mixture" of different religions or any heterodox beliefs. ${ }^{35}$ The pattern in which he writes has a manner, in which verses of the Qur'ān, Prophetic sayings, concepts of theoretical mysticism, a mystical interpretation of Qur 'ān and Hadith ( $\left.t a^{\prime} w i ̄ l\right)$ are applied within an Islamic context. It is in such a manner that, from Baba Rexheb's perspective, no doubt remains whether Bektashism is a mixed religion, a pagan movement, or Shi' ite extremism (Ghuluw). ${ }^{36}$

34 For more on the notion of Divine Sayings, see A. Graham William, "Ḥadìth Qudsī," in Encyclopaedia of Islam, Three, Encyclopaedia of Islam (Brill).

35 There are accusations of heterodoxy to the Bektashi Order. Hamid Algar in his BEKTĀŠǏYA entry in Encyclopedia Iranica defines the Bektashi order as "a syncretic and heterodox Sufi order." He then discusses the interpenetration of the Bektashi and Qizilbaāsh Orders, as a result of which "numerous elements of Shicite provenance entered Bektāšĩ usage." When he describes the way in which a follower is initiated into the Bektashi Order he states that "Initiation into the Bektāšĩ order thus included a formal profession of faith in Twelver Shīišsm." This, however, according to Algar does not "entail obedience to Shīite legal ordinances." See Algar, "Bektāšīya." While Algar indicates that "alcohol was consumed and women participated freely in the ceremony, dancing together with men, [which] gave rise to persistent accusations of debauchery." Ibid. Frances Trix narrates how Baba Rexheb did not consume alcohol during the Muhabbat or how Ali Hakki [Haqi] Baba, fought with those who consumed alcohol in his lodge in Albania. Trix, The SufiJourney of Baba Rexheb, 36. There is no doubt that consuming alcohol has been performed in some lodges, but it is also evident that some other Baba's oppose it. Baba Rexheb gives an interpretation and definition of the Bektashi order that is compatible with the whole history of Islamic Sufism. In this sense, Baba Rexheb's writings and what Trix narrates from him does not support Algar's definition of the Bektashi Order as heterodox or debauched. On the other hand, Riza Yildirim, in his Ph.D. dissertation, mentions that Qizilbashs took asylum in the Bektashi Order: "All these 'anarchic' and heterodox groups found asylum in the Bektashi Order, which proved the approval of the regime. Ottoman administration, on the other hand, regarded it useful to canalize this unstable social energy into the Bektashi Order so that they would pose less threat to the socio-political order of the Ottomans" (Yildirim 2008, 70) See also Riza Yildırım, "The Safavid-Qizilbash Ecumene and the Formation of the Qizilbash-Alevi Community in the Ottoman Empire, C. 1500-C. 1700," Iranian Studies 52, no. 3-4 (2019). Regarding the above-mentioned quotes and discussion, the question is whether Qizilbāsh-Bektashi relation was an "influence" as Algar states, or "taking asylum" as Yildirim mentions, or it happened based on the common creeds or because of the Qizilbāsh sociopolitical crisis?

36 Moosa Matthew (1987), among the others, categorizes the Bektashi Order as extremist Shi' ites who deified Ali. See Moosa, Extremist Shiites: The Ghulat Sects. Baba Rexheb's Misticizma Islame dhe Bektashizma does not introduce such a notion at all. 
To summarize, chapters of the first part include the foundation of spirituality, the early centuries of Islamic spirituality, the formative period of Sufism, the foundations of the Sufi orders, the fifth century of Islamic spirituality, and spirituality and philosophy.

The second part is devoted to various Sufi orders and especially the Bektashi order and its principles and creeds. In the section on the Bektashi Order, the initial point of Baba Rexheb is that it is an Islamic mystical order that deals with the perfection of the human soul. ${ }^{37}$ The wayfarer in this Order should seek proximity and love toward God, purifying himself from all worldly and material desires and replacing them with his beloved in order to reach annihilation in God (Fanā Fillāh) and then to survive in a state of subsistence to God (Baqā Billāh). Following the tradition of Islamic Mysticism in which "love" plays a canonical role, Baba Rexheb explains the interrelation between the lover and the beloved ${ }^{38}$ as follows:

The beloved is the one who constantly circulates in the eyes of the lover. The one who occupies the heart and intoxicates the lover as such that whenever he/she looks, he/she sees nothing but the Beloved. Moreover, when he/she looks in the mirror and sees him/herself, it seems that he/she only finds the Beloved...the beauty of love that has embarrassed (filled) the sky and the earth has circled all universe. ${ }^{39}$

Baba Rexheb again reflects the Islamic Sufi tradition and comments on its principles and shows the interconnection of the Bektashi Order with that tradition.

In speaking of Bektashi principles and their relation to the principles of Islam, Baba Rexheb stresses that "Bektashism follows and respects all Islamic commands and practices. Its foundation is Qur' an and prophetic traditions (Hadith)." He continues to express that Bektashism "worships Allah the exalted and prays to Him, Knows God as the lord of the absolute power and creator of all existence being. Admires Prophet Muhammad and have great respect for Ali." ${ }^{140}$ As mentioned, the basic creeds explained by Baba Rexheb suggest none of the extremist elements. In agreement with many Sufi orders, he emphasizes that Ali is the King of the saints (Shāhi Evlija) who knows what

Rexhebi, Misticizma Islame Dhe Bektashizma, 121.

Chittick reminds us that a Prophetic tradition ascribes the love relationship between man and God. When Gabriel asks Muhammad what "doing the beautiful" (al-Ihsān) means, he replies that: "Doing the beautiful is that you worship God as if you see Him, for if you do not see Him, surely He sees you." Meybudi, the Persian Sufi, referring to this Hadith, says that: "This hadith is an allusion to the heart's encounter with the Real, the secret core's convergence with the Unseen, and the spirit's contemplation of the Protector. It is an incitement to sincerity in acts, letting go of wishes and loyalty to what was accepted on the First Day". See William C. Chittick, Divine Love Islamic Literature and the Path to God, (New Haven: Yale University Press, 2013). 224.

39 Rexhebi, Misticizma Islame Dhe Bektashizma, 148.

40 Ibid., 122. 
is secret and mysterious of the universe and Wilayah from Prophet Mohammad. ${ }^{41}$ This too is common with the Shia creeds generally. Thus, as Baba Rexheb puts it, Bektashi principles and doctrines could be summarized as follows:

- Belief in God as Absolute Power and Creator, and faith in and respect to the Holy Quran

- Following the prophetic tradition

- Denying the claims that the Bektashi Order has gone astray or deviated from the Qur'an and Prophetic Hadith and tradition

- Respect and love of the household of the prophet, especially Ali, Fatimah, Hasan, and Hossein. The Bektashi Order regards Ali as master of Evliā (saints). ${ }^{42}$

- Islam in the view of the Bektashi Order is a religion of logic and reason; therefore, the performance of the prayers must be accompanied by understanding and awareness of the inner meaning.

- Expression of the importance of Muslims' daily prayers (Salāt) and stress on the importance of understanding the meaning of religious duties, otherwise religious practice will be a mere imitation. ${ }^{43}$

To avoid accusations and misunderstanding, while explaining the respect of the Bektashi order to Allah, Muhammad, and Ali, he alludes to the fact that the meaning and importance that Bektashis give to Allah-Mohammad and Ali is misinterpreted by all those who prefer to fight and despise Bektashi principles. ${ }^{44}$

Baba Rexheb's account of the Bektashi creeds is reflective of the Order as a whole. In fact, a great deal of Erkan-name's, or ritual-books, by Bektashi babas ${ }^{45}$ share the same view. Muhammet Ali Hilmī Dedebaba (1842-1907), for instance, begins his Erkanname with a prayer to God and salutation to Ahl al-Bayt, and he plays with these concepts through his Divān-i Ash'ār. Pieces of these prayers and visitations are found

Ibid.

42 In the discussion of Spiritual instruction, Baba Rexheb also adds, "Only those designated by the Prophet (i.e., the Ahl ul-Bayt, the Twelve Imâms, and the saints) are able to discern the subtleties of reality and the soul".

43 Rexhebi, Misticizma Islame Dhe Bektashizma, 127-9.

44 Ibid.

45 A manuscript Erkān Nāme of an unknown author of the Bektashi order, written in 1818 preserved in the Albanian National Archive. It for instance, presents a Shī'i call to prayer. Adhān, Iqāma, prayer times and collecting between prayers of noon and afternoon also following second Shahadah (bearing witness) in Adhān with asserting that Ali is the friend of Allah is among those points that leave no doubt of the closeness and resemblance between the Bektashi and Shī'i creeds. Following is the description of the call to prayer in this manuscript in Turkish: Keyfiyet-i ikamet; Allahu ekber Allahu ekber eşhedu ena ilahe illallah iki defa, eşhedu enne Muhammeden resulallah iki defa, ve eşhedu enne Aliyyen Veliyullah iki defa, hayye ales-salah iki defa, hayye alel-felah iki defa, hayye ala hayri'l-amel iki defa, kad kamedis salah iki defa, Allahu ekber Allahu ekber la ilahe illallah. 
in Twelver Shi'a traditions. ${ }^{46}$ Moreover, again resembling Shī'i culture, the Bektashi Erkān Nāme treatises are significantly rich and important. They present the state of Shī' 1 spirit in the Bektashi order. ${ }^{47}$ Baba Rexheb continues with a description of the rituals of initiation to the Bektashi Order.

The third section of the book is dedicated to Bektashi Sufi masters, poets, and saints. Baba Rexheb's approach is not similar to detailed historical research. Instead, he tries to enter into a conversation with those Sufis. In these conversations, he does not regard them as an object of his research, he rather has an intimacy with them and puts himself in a sympathetic dialogue with them. He breaks the historical time and joins with them in spiritual language, a simple and at the same time deep language, an approach in keeping with sufi tradition. He mentions the Bektashi poems to demonstrate how previous Babas and dervishes devoted their life to their Beloved. Following the poems, Baba writes short commentaries on some of those Sufi expressions.

Frances Trix, in her Spiritual Discourse, Learning with an Islamic Master (1993) presents the simplicity and at the same time profound nature of Baba Rexheb's teachings. As is known in Sufi studies, sometimes he applies the language of "allusion" (Ishärat) and not that of the "announced expression" ('ibārat). Primarily, this is a form of mystical language. The language of announced expression ('ibārat) will be revealed by interpretation while the language of allusion (Ishärat) needs spiritual hermeneutics which is a journey from outward (Z̄āhir) to inward (Bātin).

46 The following are instances of prayers in Muhammet Ali Hiilmī Dedebaba's (1842/1907) Erkan Name in Turkish. It clearly shows the Shì'̄- Bektashi affinities in matters related to Wilāyah and Ahl al-Bayt: Bismillahi'r-rahmâni'r-rahîm

Allahümme salli ve sellim vezid ve bârik 'alâ nûri seyyidinâ ve seyyidi'l-enbiyâ'i Muhammedin Mustafâ allahümme salli ve sellim ve bârik 'alâ nûri seyyidinâ ve seyidi'l- evliyâ'i'l-imâmü 'aliyyi'l-mürtezâ ... The following segment is quoted from the famous Shī'izièyārat 'Āshūrā:

Allahümme'l-'an evvele zâlimin zaleme hakki Muhammedin ve âhiri tâbi'in lehü 'alâ zâlike allahümme'l'ani'l-'usâyete'lletî câhedeti'l-Hüseyin ve şâye'at ve tâbe'at 'alâ katli- hi allahümme'l-'anhüm cemî‘an...See C. Erdem, "Muhammet Ali Hilmi Dedebaba Erkân-nâmesi" Turk Kult. Haci Bektas Veli - Arast. Derg. Turk Kulturu ve Haci Bektas Veli - Arastirma Dergisi 57 (2011).

47 It should not be neglected that what Baba Rexheb stated concerning the creeds is in line with the writing of almost all of the Bektashi authors. Among them is the Albanian national poet and the Bektashi author Naim Frashëri (1846-1900) in his "Fletorja e Bektashinjet" that was originally published in 1896 in Bucharest. Frashri states "The Bektashis believe in the True and Mighty God, in Muhammed - Ali, Hadijah, Fatimah, Hasan and Husein. They believe in the twelve imams that are: Imam Ali, Imam Hasan, Imam Husein, Imam Zeynel Abedin, Imam Muhammed Bakir, Imam Jafar al Sadik, Imam Musa Kazim, Imam Ali Riza, Imam Muhammed Teki, Imam Ali Neki, Imam Hasan Askeri, Imam Muhammed Mehdi.” See Naim Frashëri, Fletore E Bektashinjet (Tiranë: Naim Frashëri, 2000), 9. The statute of the Bektashi Community as well asserts the originality of the Bektashi Order in the Islamic School of Ahl al-Bayt: "Bektashism is a school of the Ehli Beit [Ahl al-Bayt], an Islamic religious doctrine and practice, which has its roots in the Quran and the teachings of the Prophet Muhammad and of the Holy Imams... ." See Statuti I Komunitetit Bektashian Shqiptar, (Vlore: Shtypshkronja "Vlora", 1924), 3. 
Confusing allusion and announced expression can lead to misreading the Bektashi position in the Sufi tradition. A good example of such misunderstanding is presented in Albert Doja's "Spiritual Surrender" where he comments on the Sufidisciple relation specifically in the case of Baba Rexheb and Trix:

But whatever such patented super-informants like Baba Rexhebi may tell us, we must not loose [sic] sight of the fact that what we are observing is exactly what they can manage to do with their ideological schemes when their prestige is at stake. $^{48}$

\subsection{Baba Rexheb and Shia Sunni Issues}

There are occasions in which Baba Rexheb raises the Shia-Sunni relationship in his conversation with Frances Trix. It is helpful to assess those thoughts to depict his understanding of the relationship between Bektashism and Shia Islam on the one hand and Sunni Islam on the other. One of the early occasions is when he describes the Bektashi lodge in Egypt where he resided for four years after fleeing from Albania to Italy and then making it to Egypt. He makes the following statement:

I saw that the tekke would be destroyed there. And it was not a good place for us because ... Naturally, being Sunni they did not like tekkes. And a day would come when they would destroy the tekke. As a matter of fact, that is just what happened. ${ }^{49}$

He explicitly shows his awareness of Sunni dislike of Tekke in the above statement. He even predicts that the Tekke would be destroyed as eventually happened. Another occasion is when Frances Trix explains how Baba narrates the suppression of the Bektashi Order in the Ottoman Empire:

In his account of the suppression of his order Baba told me how, after the Janissaries had been killed, people came forth blaming the Bektashis for the excesses and the recent sedition of these former elite troops. Hodjas, Sunni religious leaders, who had never accepted that the more Shi'a-like Bektashi should have a place in Ottoman society, spoke out publicly against them and their beliefs, insisting that they either disavow these beliefs or be executed. At this

48 Albert Doja, "Spiritual Surrender: From Companionship to Hierarchy in the History of Bektashism," Numen 53, no. 4 (2006): 483.

49 Trix, The Sufi Journey of Baba Rexheb, 23-4. On another occasion, however, he puts his departure from Egypt as follows: "I saw that the Egyptians were Sunni and that the tekke was the only Bektashi centre there. Also, the monarchy passed from there, a monarchy that had been considered Albanian and that liked Albanians and had allowed them to stay. The new regime did not like the tekke" ibid., 121. Here Baba adds a political cause for enmity for the Bektashi Tekke in Egypt in addition to the religious differences. 
point, Baba quoted the famous Bektashi saying that had been the response of many Bektashi clerics to this pressure:

Ser veririz, sirr vermeziz.

We give our heads, never our secret..$^{50}$

The above quote also explains what a historical view and action had been taking place among Bektashi and Sunni scholars of the Ottoman Empire. He also mentions the famous Bektashi saying which refers to the keeping of their secret. What could the secret be? Is that the love of the household of the Prophet and announcing of the others who called themselves Muhammad's successors as oppressors? The above narration indicates the enmity at least between Sunni and Bektashi and on the other hand, depicting the Bektashi Order as "more Shi'a-like." In this statement, it is clear that Baba does not confirm the full identity of the Bektashi Order with Shi'a Islam; nevertheless, he stresses the proximity of Shi'a Islam and the Bektashi Order. Still, on another occasion, it seems that Baba Rexheb believes that the Bektashi Order transcends the Shi'a-Sunni division. Trix states that;

Indeed, the Bektashis do celebrate the major Shi'a holidays of Ashura and Nevruz. But when I asked Baba Rexheb directly if the Bektashis were Shi'a, he responded in an old Turkish couplet implying that the Bektashis were misled neither by the Sunnis nor the Shi'a. ${ }^{51}$

This is an intriguing statement, and we may well wonder exactly how Baba Rexheb thinks that both Sunnis and Shi'a were "misled." Is he addressing the Shī'a and Sunni as two Fighī School or is he referring to their creeds? Not only Baba Rexheb but also many other Bektashi scholars such as Na'īm Frāsherī among the others have discussed the common principles and affinity between Shī'a and Bektashi creeds.

\subsection{Additional Notes On The Modern Scholarship's Misapprehension of Baba Rexheb And Shī'ì Concepts}

There is a tremendous misapprehension which has led contemporary scholars to wrongly theorize or over-simplify the Shi'i-Bektashi commonalties. In one of such instances, Stoyanov, considering the affinity of the Bektashi creeds to that of Twelver Shi'i in Baba Rexheb's Misticizme Islame dhe Bektashizma, states, "Internal development and the renewed contacts with the principal religious and theological centres of Middle Eastern Twelver Shi'ism seem to indicate that the ongoing Bektashi revival in Albania may follow a trajectory of further rapprochement with the mystical and

Ibid., 28.

Ibid., 30 .

Turkish Journal of Shiite Studies 3/1 (Haziran 2021) 
intellectual forms of Twelver Shi'ism." ${ }^{22}$ While Stoyanov mentions that Baba Rexheb's book is the most influential book in post-World War II Albanian Bektashism, ${ }^{53}$ he analyzes the proximity in creeds as a result of "internal development" and "renewed contacts" with the Twelver Shi'ism. In fact, Baba was not in contact with Twelver Shi'ism and as his account of his life is a witness to his training by traditional Bektashi babas, namely Ali Hakki [Ḥaqī] Baba and Selim Ruhị Baba in Albania. Furthermore, following the Communist regime's enmity toward religious communities and religion generally, he migrated in the 1950s to the United States of America. All these happened years prior to the fall of the communist regime and well before the Iranian Islamic revolution in 1979. The book itself was written in the mid-1960s and first published in 1970. Outside of Baba Rexheb's work, one finds the spread of Shi'i creeds in countless popular poems (Albanian: Bejtaji, Turkish: Nefes), Erkān Nāme and other Bektashi sources from the Balkans.

In a similar vein, Albert Doja's A Political History of Bektashism in Albania' attempts to provide yet another explanation as to why there is proximity to Shi'i creeds in Baba Rexheb's Misticizme Islame dhe Bektashizma. The above-mentioned "renewed contacts" of Stoyanov, in Doja's work is upgraded to the unfounded claim that Baba Rexheb has been in "contact with more sophisticated types of Sufism, read in English the works of Western Orientalists, specifically French Orientalist Henry Corbin." ${ }^{154}$ In addition to this, Doja further speculates that the whole of Baba Rexheb's project is a drastic revision of Bektashism in order to preserve the order. When Doja mentioned that Baba Rexheb read Henry Corbin, he in a footnote provided lists of the books of Corbin that Baba Rexheb supposedly read; note the dates: L'homme de lumière dans le soufisme iranien, 1971; Corps spirituel et Terre céleste: de l'Iran mazdéen à l'Iran chiite, 2e ed., 1979; Temps cyclique et gnose ismaélienne, 1982; Face de Dieu, face de l'homme: herméneutique et soufisme $1983 .{ }^{55}$ It seems that Doja ignores the fact that Baba Rexheb wrote Misticizme Islame dhe Bektashizma five years earlier than the publication of the earliest named work of Corbin, namely the L'homme de lumière dans le soufisme iranien. Therefore, historically he was not able to read books that were not published yet. Even if the dates were accurate, there is evidence that Baba Rexheb was not well enough versed in French and English to read those sophisticated and scholarly works. Doja provides no evidence for this claim, and Trix, as a keen disciple of Baba Rexheb, responded to our question concerning Baba's language ability as follows:

\footnotetext{
52 Stoyanov, "Contested Post-Ottoman Alevi and Bektashi Identities in the Balkans and Their Shi'Ite Component," 187.

53 Ibid.

54 Albert Doja, "A Political History of Bektashism in Albania," Totalitarian Movements and Political Religions 7, no. 1 (2006): 102

55 Ibid.
} 
Baba did not read English well. Thus, he did not come into contact with Corbin in English when he came to America. His main reading on Sufism in the US was of the works he had requested from Egypt of traditional works in Arabic, Persian, Ottoman Turkish, and Albanian.... Again, I do not think Baba ever read Corbin. He read much in Egypt from traditional sources from 1948 to 1952, and later from books that he requested from Egypt in Arabic, Persian, Ottoman Turkish and Albanian. No "drastic revision" here. ${ }^{56}$

We have, moreover, Trix's description of Baba Rexheb's desk and the books that were around him:

Baba rummaged on his study table that was always full of books in several languages, largely books in the Arabic script. Among my favourites were the volumes of the Ottoman Turkish encyclopedia, Kāmus-e Al-âlam, first published in 1889-1898 in Constantinople by Sami Bey Frashëri, the great Ottoman lexicographer who also happened to be Albanian. Baba located a thin dark book in Ottoman Turkish, by Ahmed Rifat, the Mirror of Intentions on the Refuting of Abominations, a defense [sic] of Bektashism published in $1863 .{ }^{57}$

It is evident then that Baba Rexheb's work was neither under influence of "the renewed contacts" with Twelver Shi'ism per Stoyanov, nor "contact with more sophisticated types of Sufism... specifically French Orientalist Henry Corbin" per Doja. His work rather demonstrates the traditional Bektashi creed based on what the Sufi authors of this Order created first in conversation with Islamic culture, and secondly from their love and devotion to the Ahl al-Bayt. There is no doubt that our understanding of religion and its concepts and creeds naturally develops over time and space. Baba Rexheb and the Bektashi Order are not exceptional in this case. Attributing any development in thought as an attempt to "drastically change in the Bektashi Order" or "what they can manage to do with their ideological schemes when their prestige is at stake" do not capture the core concepts of devotional religiosity in the writings of a Sufi such as Baba Rexheb. We could take Sayyīd Ḥaydar Āmulī (d. ca. 787/1385) or Sayyid 'Alī Qādị Ṭabāṭabā’ì (1866-1947) as instances of two Twelver Shi'i scholars who considered the interrelation between Shi'ism and Sufism and an obvious matter. $^{58}$

\footnotetext{
Frances, Trix. Email correspondence with the author, January 6, 2020.

Trix, The Sufi Journey of Baba Rexheb, 20.

Sayyīd Haydar Āmulī (d. ca. 787/1385) in his Jāme` al-asrār wa manba` al-anwār mentions that "the origin, offspring, and references of both [Shi'ism and Sufism] are the same. It is because the reference of all of the sects of Shi'a, especially the Imämiyyah branch, is none except the commander of the faithful Ali and his children and children of his children. And the source and offspring of all of them and references for their knowledge and principles are the God almighty. The real Sufis share the same reality. They adduce their knowledge and their cloak (Khirqah) to 'Ali and after him to his children and children of his children..." see
} 


\section{Conclusion}

Both post-Ottoman and contemporary scholarships have described the Bektashi Order in many different and opposing ways. In trying to understand its nature and doctrines, one cannot ignore the political crises which have wracked the Balkans and nor the biases of scholars who were serving various political systems and nationalistic ideologies.

Baba Rexheb's Misticizma Islame dhe Bektashizma gives us an important insight into the nature and principles of the Bektashi Order and its relation to Islamic Sufism in general and Shi'i Islam in particular. Baba Rexheb's work plays a significant role in making a bridge between the Ottoman, post-Ottoman, and contemporary understanding of the Bektashi Order. This book, despite some modern attempts to undermine it, sheds light on the nature and principles of Bektashi Order from within the tradition which allows a more accurate assessment of post-Ottoman scholarship.

By closely attending to Baba Rexheb's approach to mysticism, the definition of Sufism and mystical concepts, along with his careful explanation of the Bektashi doctrine, there remains no doubt that the Bektashi Order principally is an Islamic Order. Moreover, its way of interpreting Islamic creeds aligns it closely with Shi'a creeds, what we might call, following Pazūkī, "Spiritual Shi'ism." ${ }^{59}$ At the same time, Bektashism, like other Sufi orders, has produced its own extensive literature while sharing and borrowing from other Sufi traditions. We also emphasized on some misreadings in some historic and modern understandings of Bektashism based on what Baba Rexheb depicts of this order. We noticed that there was an attempt from scholars

Ḥaydar ibn 'Alī Āmulī, Henry Corbin, and 'Uthmān Yahyá, Jāmi' Al-Asrār Va Manba' Al-Anvār: Bih InzImām-i, Risālah-i Naqd Al-Nuqūd Fī Márifat Al-Vujūd ([Tehran]: Anjuman-i İrānshināsī-i Farānsah, 1989), introduction. Sayyid 'Alī Qāại Ṭabāțabā'ì (1866-1947) was a Sufi-Shī’i figure in Najaf Seminary contemporary to Baba Rexheb. It is narrated from him, that "the best man is a Sufi Faqih"; in trying to reconcile Shī'ism with Sufism. For more on this question, see Seyed Mohammad Hasan Qāḍi, Āyat Al-Haq (Tehran, Iran: Intishārāti Hikmat, 1392), 231. Also, SeyedAmirHossein Asghari, "Shi'a Mystical Theology: Notes on Sayyid Haydar Āmulī’s Jāmi“ Al-Asrār Wa Manba' Al-Anwār," Kom Casopis Za Religijske Nauke 9, no. 3: 65-80 (2020). DOI: $10.5937 / \mathrm{kom} 2003065 \mathrm{~A}$. For more on the philosophical and Sufi interpretation of religion, and metaphysical aspect of shiism see "-- Ontology and Cosmology of the 'aql in Șadrā's Commentary on Ușūl Al-Kāfī," Journal of Shi'a Islamic Studies 10, no. 2 (2017). DOI: https://doi.org/10.1353/isl.2017.0011; Seyed Amir Hossein Asghari: Presence, Manifestation, and Visitation in Abrahamic Religions: The Notion of "Presence" in Shi'ism, Journal of Religious \& Theological Information, (2021) https://doi.org/10.1080/10477845.2021.1926629

59 For more on the notion of "Spiritual Shīìsm" see: Pazūkī, Shahrām, Spiritual Walayah or Love in Seyed Ghahreman Safavi, Rumi's Spiritual Shi'ism ([London]: London Academy of Iranian Studies Press, 2008). This chapter discusses Shi'ism beyond the boundaries of jurisprudence and places more stress upon the originality and primacy of Spiritual devotion and surrender to Walāyah-rather than following a particular juristic school-as an important element of Shi' ism. 
like Albert Doja to discredit Baba Rexheb's work and result that it has borrowed from intellectuals like Corbin or Iranian thinkers. In response we showed the problems of this claim and its historical impossibility. This paper concludes that the authenticity of Baba Rexheb's work lies on his authentic relation with the chain of the traditional Bektashi master from Albania to Turkey.

\section{Bibliography}

al-Kalabadhi, Abu Bakr Muhammad Ibn Ibrahim, and A.J. Arberry. "The Doctrine of the Sufis = Kitab Al-Taarruf Li-Madhhab Ahl Al-Tasawwuf." [In English]. (1977).

Algar, Hamid. "Bektāšĩya." In Iranica, 1989.

Amir-Moezzi, Mohammad Ali, Eric Ormsby, and Hasan Ansari. "Silent Qur'an and the Speaking Qur'an : Scriptural Sources of Islam between History and Fervor." [In English]. (2016).

Āmulī, Ḥaydar ibn 'Alī, Henry Corbin, and 'Uthmān Yahyá. Jāmi' Al-Asrār Va Manba' AlAnvār: Bih Inžimām-I, Risālah-i Naqd Al-Nuqūd Fì Ma'rifat Al-Vujūd. [in Persian] [Tehran]: Anjuman-i İrānshināsī-i Farānsah, 1989.

Asghari, SeyedAmirHossein. "Ontology and Cosmology of the 'aql in Șadrā's Commentary on Ușūl Al-Kāfî." Journal of Shi'a Islamic Studies 10, no. 2 (2017): 157-82. DOI: https://doi.org/10.1353/isl.2017.0011

Asghari, SeyedAmirHossein. "Presence, Manifestation, and Visitation in Abrahamic Religions: The Notion of "Presence" in Shi'ism, Journal of Religious \& Theological Information, DOI: 10.1080/10477845.2021.1926629.

Asghari, SeyedAmirHossein. "Shi'a Mystical Theology: Notes on Sayyid $\mathrm{H}$ Aydar Āmulī’s Jāmi 'Al-Asrār Wa Manba“ Al-Anwār." Kom Casopis Za Religijske Nauke 9 , no. 3 (2020): 65-80. DOI: 10.5937/kom2003065a

Baharlu, İlgar. "Pre-Safavid Sema (Semah) Accompanied with Sufi Classics." Journal of Alevism-Bektashism Studies 22 (2020): 179-98.

Birge, John Kingsley. The Bektashi Order of Dervishes. [in English] 2015.

Browne, Edward Granville. Further Notes on the Literature of the Hurufis and Their Connection with the Bektashi Order of the Dervishes. [in English] [Hertford]: [S. Austin], 1907.

Chittick, William. "Ibn 'Arabî." In The Stanford Encyclopedia of Philosophy edited by Edward N. Zalta, Spring 2020 Edition.

Chittick, William C. Divine Love Islamic Literature and the Path to God. New Haven: Yale University Press, 2013. 
Clayer, Nathalie. "The Bektashi Institutions in Southeastern Europe: Alternative Muslim Official Structures and Their Limits." Die Welt des Islams 52, no. 2 (2012): 183-203.

Davey, Richard. The Sultan and His Subjects. A new ed. London: Chatto \& Windus, 1907. Doja, Albert. "A Political History of Bektashism in Albania." Totalitarian Movements and Political Religions 7, no. 1 (2006/03/01 2006): 83-107.

Doja, Albert. "Spiritual Surrender: From Companionship to Hierarchy in the History of Bektashism." Numen 53, no. 4 (2006): 448-510.

Elsie, Robert. The Albanian Bektashi : History and Culture of a Dervish Order in the Balkans. London: I.B.Tauris, 2019.

Erdem, C. " Muhammet Ali Hilmi Dedebaba Erkân-nâmesi." [In Turkish]. Türk Kültürü ve Hacı Bektaş Veli - Arastirma Dergisi 57 (2011): 245-58.

Frashëri, Naim. Fletore E Bektashinjet. [in Albanian] Tiranë: Naim Frashëri, 2000.

Galland, Antoine, Nahid Sırrı Örik, Charles Henri Auguste Schefer, and Dil ve Tarih Yüksek Kurumu Atatürk Kültür. İstanbul'a Ait Günlük Hatıralar (1672-1673). [in Turkish] Ankara: Türk Tarih Kurumu Basımevi, 1998.

Gramatikova, Nevena. "Ethnology of Sufi Orders: Theory and Practice. Proceedings of the British-Bulgarian Workshop on Sufi Orders." Paper presented at the the British-Bulgarian Workshop on Sufi Orders, 2000.

Gramatikova, Nevena, and International Centre for Minority Studies and Intercultural Relations. Neortodoksalniīi IstiàM V BŭLgarskite Zemi: Minalo I SŭVremennost. [in In Bulgarian, with summary in English.] 1. izd. ed. Sofiiia: IK "Gutenberg", 2011. Moosa, Matti. Extremist Shiites: The Ghulat Sects. Contemporary Issues in the Middle East. 1st ed. Syracuse, N.Y.: Syracuse University Press, 1987.

Qādī, Seyed Mohammad Hasan Āyat Al-Haq. Tehran, Iran: Intishārāt-i Hikmat, 1392. Ramsaur, Ernest Edmondson. The Young Turks; Prelude to the Revolution of 1908. Princeton Oriental Studies: Social Science,. Princeton, N.J.,: Princeton University Press, 1957.

Rapoport-Albert, Ada, and Deborah Greniman. Women and the Messianic Heresy of Sabbatai Zevi : 1666--1816. Littman Library of Jewish Civilization. Oxford ; Portland, Or.: Littman Library of Jewish Civilization, 2011.

Rençber, Fevzi. Hakk Muhammed Ali Aşkı : "Adıyaman Alevileri". [in Turkish] 2014.

Rexhebi. Misticizma Islame Dhe Bektashizma. New York,: Printed by Waldon Press, 1970.

Safavi, Seyed Ghahreman. Rumi's Spiritual Shitism. [in English] [London]: London Academy of Iranian Studies Press, 2008.

Schimmel, Annemarie. Mystical Dimensions of Islam. Chapel Hill,: University of North Carolina Press, 1975. 
Şişman, Cengiz. "Sabatay Sevi." In TDV İslâm Ansiklopedisi, 334-5: TDV İslâm Araştırmaları Merkezi, 2008.

Statuti I Komunitetit Bektashian Shqiptar. [in Romanian] Vlore: Shtypshkronja "Vlora", 1924.

Stoyanov, Yuri. "Contested Post-Ottoman Alevi and Bektashi Identities in the Balkans and Their Shi'Ite Component." In Shi'i Islam and Identity : Religion, Politics and Change in the Global Muslim Community, edited by Lloyd V. J. Ridgeon. London; New York: I.B. Tauris : Distributed in the United States and Canada exclusively by Palgrave Macmillan, 2012.

Trix, Frances. The Sufi Journey of Baba Rexheb. 1st ed. Philadelphia: University of Pennsylvania Museum of Archaeology and Anthropology, 2009.

Üçer, Cenksu. Tokat Yöresinde Geleneksel Alevilik. [in Turkish] Ankara: Ankara Okulu Yayınları, 2015.

Vorhoff, Karin. "'Let's Reclaim Our History and Culture!": Imagining Alevi Community in Contemporary Turkey." Die Welt des Islams 38, no. 2 (1998): 220-52.

William, A. Graham. "Hadìth Qudsī." In Encyclopaedia of Islam, Three. Encyclopaedia of Islam, 000: Brill.

Yildırım, Riza. "The Safavid-Qizilbash Ecumene and the Formation of the QizilbashAlevi Community in the Ottoman Empire, C. 1500-C. 1700." Iranian Studies 52, no. 3-4 (2019/07/04 2019): 449-83.

Yıldız, Harun. Anadolu Aleviliği: Amasya Yöresi Bağlamında Bir İnceleme. [in Turkish] Ankara: Ankara Okulu Yayınları, 2014.

Zarcone, Thierry, and Angela Hobart. Shamanism and Islam: Sufism, Healing Rituals and Spirits in the Muslim World. [in English] 2017.

\section{Additional Resources}

Ocak, Ahmet Yaşar. "Babaîler İsyanından Kızılbaşlığa: Anadolu'da İslâm Heterodoksisinin Doğuş ve Gelişim Tarihine Kısa Bir Bakış". Belleten, LXIV/239, 2000, 129-159.

Ocak, Ahmet Yaşar. Bektaşi Menâkıbnâmelerinde İslam Öncesi İnanç Motifleri, İstanbul, 1983.

Amir-Moezzi, Mohammad Ali, Christian Jambet, Kenneth Casler, and Eric Ormsby. What Is Shi'i Islam?: An Introduction. Abingdon, Oxon: Routledge, 2018.

Baharlu, İlgar. Şah'ın Bahçesinde Şah İsmail Öncesi ve Sonrası Kızılbaşlık. İstanbul: Kitabevi Yayınları, 2020. 
Aṣgharī, Sayyid Amirhossein, Aṣgharī, Seyedeh Leila, Aṣgharī Sayyid 'Alī, Lohja, Edin, Hadroj, Bahrije, Shehu, Hajri, Fjalor Persisht - Shqip: Farhang-i Vāzhah-I Fārsī - Shīp (Ālbāniyāyī). Bot. i 1-rë. Tiranë: Botimet Toena, 2010.

Duijzings, Ger. "Religion and the politics of 'Albanianism': Naim Frashëri's Bektashi writings." In Albanian Identities: Myths, Narratives and Politics, by Stephanie Schwandner-Sievers and Bernd J. Fischer (eds, 60-69. London: Hurst, 2002.

Elsie, Robert. Historical Dictionary of Albania and Raymond Hutchings. Lanham: MD: Scarecrow, 2004.

Franklin Lewis, "Tarīqah," The Encyclopedia of Religion, Second Edition, ed. Lindsay Jones [original ed. Mircea Eliade; original article, A.H. Johns] (MacMillan Reference / Thomson Gale, 2005), 13: 9003-9015

Frashëri, Naim. Fletore e Bektashinjet. Tiranë: Naim Frashëri, 2000.

Hafizović, Rešid. Islamic Studies 47, no. 2 (2008): 269-73. www.jstor.org/stable/20839122. Hasluck, F. W. "Geographical Distribution of the Bektashi" The Annual of the British School at Athens (British School at Athens, 1916) 84-121. http://www.jstor.org/stable/30102759.

Köprülü, Fuat. Türk Edebiyatında İlk Mutasavvıflar, Ankara, 1976.

Köprülü, Mehmet Fuat, Gary Leiser, and Robert Dankoff. Early Mystics in Turkish Literature. London: Routledge, 2006.

Norris, H. T. Popular Sufism in Eastern Europe: Sufi brotherhoods and the dialogue with Christianity and 'heterodoxy'. New York, NY: Routledge, 2011.

Renard, John. Tales of God's Friends: Islamic Hagiography. In Translation/Berkeley: University of California Press, 2009.

Ringgren, Helmer. "The Initiation Ceremony of the Bektashis". In the Initiation Ceremony of the Bektashis, Leiden, The Netherlands: Brill, 1965. doi: https://doi.org/10.1163/9789004378018_022

Schwandner-Sievers, Stephanie and Bernd Jürgen Fischer. Albanian Identities: Myth and History. Bloomington: Indiana University Press, 2002.

Topuzkanamis E. "Bir Bektaşî erkânnamesi". Türk Kültürü ve Hacı Bektaş Veli- Araştırma Dergisi, 2010. 55: 421-436.

Trix, Frances. Spiritual Discourse: Learning with an Islamic Master. Philadelphia: U of Pennsylvania. 1993. 